\title{
Analysis of technological aspects in the development of smart cities in Indonesia
}

\author{
Rahayu Safitri ${ }^{1}$ and Ratih Dyah Kusumastuti ${ }^{1 *}$ \\ ${ }^{1}$ Department of Management, Faculty of Economics and Business, Universitas Indonesia, Depok, \\ 16424, Indonesia
}

\begin{abstract}
Smart City concept has been proposed as one of the solutions to urban problems. This study aims to analyze the potential for smart city development in Indonesia from the aspects of information and communication technology. The secondary data of ICT elements in Indonesia is used to assess the condition of ICT in Indonesia and the country's readiness to implement the smart city concept. The data collection was carried out using a literature study. The ICT elements used in the analysis are from the smart city's five pillars of leverage domain, proposed by Bounachi and Korabat (2018), namely connectivity, data center, data analytics, applications, and end-users. The results of this analysis indicate that the Indonesian people from year to year experience an increase in the number of users of computers and cellphones which are ICT devices. However, in other parts of the pillar, Indonesia still needs a lot of improvement, especially in data center construction. This needs to be improved in order to maximize the storage and use of data obtained from end-users such as citizens, residents, visitors, government, public agencies, and private businesses.
\end{abstract}

\section{Introduction}

Indonesia is a developing country that strives to improve the standard of living of its people in all aspects. The United Nations has adopted the Sustainable Development Goals (SDGs) to balance the social, economic and environmental aspects of sustainable development, since the UN Sustainable Development Summit in 2015. The SDGs have 17 objectives, 169 targets and 226 indicators, and form the UN 2030 agenda of an internationally recognized sustainable framework [14]. In this study, the objectives of sustainable development will be reviewed in the context of smart city in relation to SDGs number 11. The Smart City concept emerged from the need for innovative solutions to solve the challenges of population growth and reduce urbanization. Globally the urban population is increasing. In $2018,55 \%$ of the world's population lived in cities, and it is projected to reach $68 \%$ by 2050 [16].

Researchers have used the term smart city since its appearance in the early 1990s [3]. The term replaced the specifically defined visions [13], such as 'knowledge city', 'digital city', 'intelligent city', 'information city', 'green city', 'low carbon city', and 'eco city' [10].

\footnotetext{
* Corresponding author: ratih.dyah@ui.ac.id
} 
Since then, the concept of smart city has evolved from a simple technology adoption in government services to a comprehensive system covering environmental, technological, innovation and social aspects. There are many definitions regarding smart city in various literatures. However, in this article, we will use the definition of smart city by the International Telecommunication Union (ITU). ITU defines smart city as an innovative city that uses information and communication technology (ICT) and other to improve the efficiency of urban operations, services, and competitiveness, as well as the quality of life, while ensuring that it meets the needs of present and future generations with respect for the economic, social and environmental aspects [6].

According to [4], there are six main dimensions of a smart city, namely: smart people, smart economy, smart mobility, smart governance, smart living, and smart environment. Meanwhile, [11] re-categorize and summarize the main conceptual components of smart cities into three categories of core factors, namely: technology (software and hardware infrastructure), people (diversity, education, and creativity), and institutions (policy and governance).

In most perspectives, technology, especially ICT is considered as an integral aspect of smart cities and central to the operations, design, and management of urban development [17]. Real time monitoring, Web 2.0, and big data analysis, which are the combination of ICT technologies to understand and optimize business, social, and public life processes, has appeared in various definitions of smart city, underlining the innovative, creative and complex development process of urban ecosystems [15]. Municipal administration, transportation, health care, education, real estate, public safety, and public utilities are some examples of digital entities in the smart city ecosystem.

Washburn et al. [19] view smart city as a collection of smart computing technology applied to critical infrastructure components and services. Intelligent computing refers to "a new generation of integrated hardware, software, and network technology that provides information technology systems with real-time awareness of the real world, and further analytics to assist people in making smarter decisions about alternatives and actions that will optimize business processes and business balance sheet results" [19].

To be a smart city we need technology as the key because the use of information and communication technology can change life and work in the city in a significant and fundamental way [4]. Information technology infrastructure and applications are the prerequisites, however, without the real involvement and a willingness to collaborate and work together between public institutions, voluntary organizations, citizens, private sectors and school, a smart city will be difficult to achieve [9].

To be able to improve the services offered by any sector and its performance, ICT can be used as it will allow for the cooperation between different sectors. Therefore, to develop and manage cities, we need to collect information about what is happening in each sector and how the interactions in these various sectors. At present, the city system operates in silos and there is little or even no coordination between them [2]. To collect data from these sectors and process it in real time, we can use ICTs as a bridge to bring them together.

Smart city projects can be a part of a city's long-term strategy. However, many cities fail to understand this. As a result, information technology is not fully utilized to upgrade and manage cities and their resources in a better way. Guides and toolkits to address the challenges of digital transformation have been developed by several organizations and researchers. For example, to help implementing ICT to achieve smarter health systems, the World Health Organization (WHO) has developed a National eHealth Strategies [18].

In Indonesia, the implementation of the smart city concept has been started since 2017 as a solution to various urban problems through the Movement Towards 100 Smart Cities, which was launched by the Ministry of Communication and Information. Several cities were selected as the pioneers in the movement, such as Bandung, Tangerang, Bekasi, 
Bogor, and Cirebon [7]. This study aims to examine the conditions of the ICT aspects for the development of smart cities in Indonesia through a literature review. The results of this study are expected to provide input on the aspects of ICT that must be prepared/improved in the development of smart cities in Indonesia.

\section{Method}

This study uses secondary data to obtain ICT elements that will be used to assess Indonesia's readiness in developing smart cities and the condition of ICT in Indonesia. Data collection was carried out using literature study, both international literature and local literature. The ICT elements used in the analysis come from the smart city's five pillars of leverage domain proposed by [9], while secondary data on Indonesia's ICT conditions are obtained from literature as well as from various sources on the Internet.

\section{Results and discussion}

ICTE-MM (ICT in School Education Maturity Model) is a model developed to assess ICT in the capability and maturity of a school. There is also an eGov-MM that was developed to evaluate the use of ICT for good governance. To assess the performance of a smart city, a model is needed that allows evaluation of the use of ICT not only in government or education, but in all city sectors such as the maturity model proposed by IDC (International Data Corporation). The IDC model was developed to evaluate urban intelligence. A maturity model for smart cities has been developed by IDC to help cities assessing their positions in terms of government processes, ICT readiness, coordination, data governance, and collaboration [10].

[9] poposed a maturity model that allows evaluating urban intelligence based on data consumed and produced by the city. The model proposed is called DQSC-MM (Data Quality Driven Smart Cities Maturity Model) and performs an assessment based on the data. DQSC-MM is structured from three main elements, one of which is the leverage domain (LD). DQSC-MM is structured from 5 pillars of leverage domains covering various layers of smart city and intersecting with data quality dimensions, the five pillars are connectivity, data center, data analytics, applications, and end-users.

\subsection{Connectivity}

In using cellular telecommunications, there are generations of communication networks that are born gradually, such as $2 \mathrm{G}, 3 \mathrm{G}, 4 \mathrm{G}$, and $5 \mathrm{G}$. The difference between these communication networks lies in the performance and data rates. The newer the generation, the better the performance and data speed. Until now, the most recent generation of communication networks in Indonesia is the 4G (LTE) network. In 2016, Indonesia together with local operators committed to cover big cities and districts with a strong fourth generation signal. Then, this effort also penetrated into hard-to-reach areas in the archipelago. Based on data provided by the Ministry of Communication and Informatics (Kominfo), equal distribution of cellular coverage has been carried out with $2 \mathrm{G}, 3 \mathrm{G}$, and 4G network services covering 83,218 rural/urban areas in Indonesia (see Fig. 1). The 4G cellular network has the lowest penetration because it is only connected to $73.77 \%$ or 61,390 villages/wards [12]. 


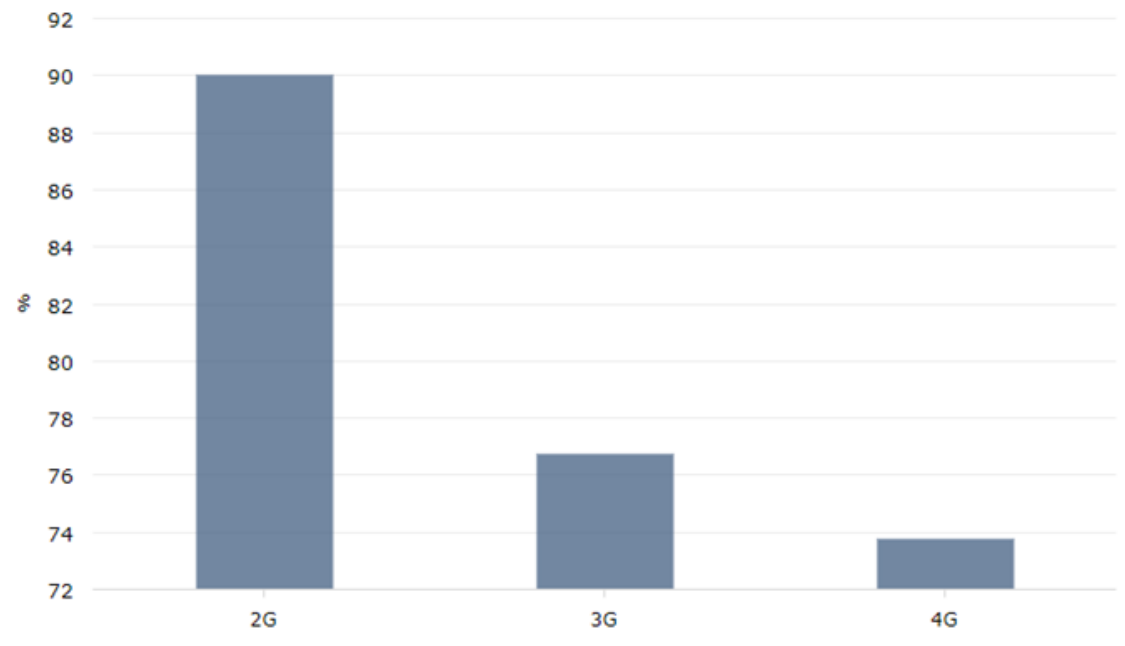

Fig. 1. Village/Kelurahan cellular network in Indonesia 2018 [12].

\subsection{Data center}

In its application in Indonesia, the Minister of Communication and Information Technology said that the new government will build an integrated data center that will become the government's national data center in Jakarta and in the new capital city. This was decided after the government agreed to build a data center in Indonesia which has been initiated since 2015. The construction is planned to start in 2020 and data will begin to be integrated by the government in 2023. Currently, government data is spread across 2,700 data centers. with a storage capacity of 36 petabytes or 36 million gigabytes. The Ministry of Communication and Information Technology predicts that Indonesia will need around 82 petabytes, while for the next 15 years Indonesia will need around 140 petabytes [1].

\subsection{Data analytics}

In Indonesia, an example of a work unit that has implemented data analytic techniques is the Directorate General of Taxes (DGT). DGT as the tax authority in Indonesia has the authority to collect evidence and then based on that evidence determines tax for taxpayers who do not carry out tax obligations in accordance with applicable regulations. One form of evidence is data stored in electronic form. The development of information and communication technology has led to the discipline of data analytics which can be used by tax authorities to process electronic data so that it can be used to support decision making in tax administration. By implementing the use of data analytics, it is hoped that it can reduce the difference between the amount of tax received or already paid and the amount of tax that should be paid [3].

\subsection{Applications}

One of the characteristics of a smart city is its ability to collect and use data generated by residents and governments in the city, which is then used to improve the quality of people's lives by improving the quality of public services provided [8]. The data collection process is carried out across the application layer using multiple platforms such as mobile devices and web services (for example, tablets or smartphones). Smart applications offer end-users 
the possibility to capture, generate and process large amounts of information and data greetings in real time.

Applications whose functions are created can be linked to various smart things that support smart city development, such as smart transportation, smart urban management, smart public services, or smart medical treatment. As one example, in Indonesia, especially the city of Medan, the concept of an intelligence transportation system based on information systems and applications on smartphones has been planned to support smooth traffic on roads. The problem of congestion is a problem in the city of Medan because the increase in the number of vehicles and the increase in road length has a very large gap. Therefore, a system that can be run in the short term and at a relatively lower cost is to create a road traffic application in Medan such as WAZE, then create a variable message sign (VMS) in the form of a videotron specifically built for city highway traffic information. Medan, and easy to use by people with smartphones [5].

\subsection{End-users}

End-users of smart city are citizens, residents, visitors, governments, public bodies, and private businesses in the city [8]. End users are the cornerstone of smart cities, because these end-users are the data providers that will be used to create smart services, and they absorb and consume the results of the smart city initiative. Smart city residents use a variety of different devices such as smartphones, computers and cameras. These devices have the capability to capture, store, analyze and share data. They are able to process and integrate large amounts of information in real-time and highlight potential problems or emerging issues to alert citizens or governments before they become severe.

Based on data published by the Central Bureau of Statistics, in Indonesia the number of computer ownership in households continues to increase from year to year. In 2018, the percentage of households that owned computers was around 20.05 percent, an increase compared to 2012 which was only around 14.86 percent. During the 2012-2018 period, computer ownership in households increased by around 1.04 percent per year. As for cellular telephone devices, in 2018, the percentage of the population in Indonesia who owned cellular phones was recorded at around 62.41 percent. This value is much higher when compared to the condition in 2010 which only reached 38.05 percent. During the 2010-2018 period, the average increase in the percentage of the population who owned cellular phones was 3.05 percent per year. If viewed based on the classification of regions, rural areas had a greater average growth rate of population who owned cellular phones, namely 3.36 percent, compared to urban areas with 2.53 percent growth. This shows the strong penetration of cellular phones to remote rural areas.

\section{Conclusion}

The objective of this paper is to analyze the condition of ICT elements in Indonesia and the country's readiness to implement the smart city concept. Based on the analysis of five pillars of leverage domains, it can be concluded that some of these pillars still need to be improved in Indonesia. For connectivity, Indonesia is still in the fourth generation or $4 \mathrm{G}$ network, thus, the fifth-generation network $(5 \mathrm{G})$ needs to be used if it does not want to be left behind. Concerning the data centers, the country still needs a lot of improvement, as the data is still spread across 2,700 data centers and has not been integrated yet, causing limited access by users or departments. Hence, the government need to immediately start the construction of the new data center. Regarding, the application of data analytics, we have seen its use in the government, especially in the taxation sector. The use of data analytics could be implemented in other sectors as well, such as in the transportation sector 
to predict the traffic or in the education sector for equal distribution of educational facilities. For smart applications developed by the city governments, especially to support smart transportation, so far it is still in the form of planning. It is hoped that the city government can realize the use of applications to facilitate the community's mobility. Lastly, end-users in Indonesia from year to year have increased in terms of the number of computer and cellphone users. This shows that the Indonesian people are increasingly involved in the use of ICT. This research has limitations as the study is conducted by analyzing the secondary data from the literature. Future research will address these limitations by using empirical data to better capture the ICT conditions and the country's readiness to develop smart cities.

\section{Acknowledgements}

This study is funded by the Ministry of Research and Technology/Bureau of National Research and Innovation, contract number NKB-79/UN2.RST/HKP.05.00/2020.

\section{References}

1. A. Aziz, A. Taher, retrieved from https://tirto.id/kominfo-klaim-pusat-data-centersiap-digunakan-paling-lambat-2023-eB1q

2. B. Paul, retrieved from https://www.budde.com.au/Research/2015-Australia- EHealth-E-Education-E-Government

3. A. Darono, Jurnal Teknik Informatika dan Sistem Informasi 6, 195-211 (2020)

4. R. Giffinger, C. Fertner, H. Kramar,R. Kalasek, N. Pichler-Milanovic, E. Meijers, Smart Cities - Ranking of European Medium-sized Cities, Research Report (University of Technology, Vienna, 2007)

5. R.G. Hollands, City 12(3), 303-320 (2008)

6. L.S. Hsb, P. Hariani, J.S. Hsb, Jurnal Pembangunan Perkotaan 5(2), 50-58 (2017)

7. ITU-T FG-SSC, Technical Report on Smart Sustainable Cities: An analysis of definitions. United Nations, International Telecommunication Union (ITU-T), Focus Group on Smart Sustainable Cities (FG-SSC) (2014)

8. P. Kominfo, retrieved from https://kominfo.go.id/content/detail/11656/langkahmenuju-100-smart-city/0/sorotan_media

9. Z. Korachi, B. Bounabat, Data driven maturity model for assessing smart cities, in Proceedings of the 2nd International Conference on Smart Digital Environment (2018)

10. H. Lindskog, Smart communities initiatives, in Proceedings of the 3rd ISOneWorld Conference, Las Vegas (2004)

11. M. De Jong, S. Joss, D. Schraven, C. Zhan, M. Weijnen, J. Clean. Prod. 109, 25-38 (2015)

12. T. Nam, T.A. Pardo, Conceptualizing smart city with dimensions of technology, people, and institutions, in Proceedings of the 12th Annual International Digital Government Research Conference on Digital Government Innovation in Challenging Times (2011)

13. $\mathrm{Y}$ Pusparisa, retrieved from https://databoks.katadata.co.id/datapublish/2019/10/17/4g-jaringan-seluler-denganpenetrasi-terendah-di-indonesia 
14. S. Caird, Urban Res. Pract. 11, 159-179 (2018)

15. The United Nations, Transforming our world: The 2030 agenda for sustainable development (2015)

16. D. Toppeta, retrieved from https://intaaivn.org/images/cc/Urbanism/background\%20documents/Toppeta_Report_005_2010. pdf

17. United Nations, World Urbanization Prospects: The 2018 Revision (2018)

18. D. Warnecke, R. Wittstock, F. Teuteberg, Sustainability Accounting, Manage. Policy J. 10(4), 654-684 (2019)

19. World Health Organization and International Telecommunication Union, National eHealth Strategy Toolkit (2012)

20. D. Washburn, U. Sindhu, S. Balaouras, R.A. Dines, N.M. Hayes, L.E. Nelson, Helping CIOs Understand "Smart City" Initiatives: Defining the Smart City, Its Drivers, and the Role of the CIO (Forrester Research, Inc., Cambridge, 2010) 